\title{
A child with neuroblastoma who presented with acute pancreatitis
}

\author{
Urmi Roy ${ }^{1}$, Md Nazmul Hassan ${ }^{1}$, AZM Raihanur Rahman ${ }^{1}$, Md Rafiqul Islam ${ }^{1}$, KM Mahbubur \\ Rahman $^{2}$, Md Rukunuzzaman ${ }^{3}$
}

Sri Lanka Journal of Child Health, 2021; 50(3): 542-545

DOI: http://doi.org/10.4038/sljch.v50i3.9744

(Keywords: Neuroblastoma, acute pancreatitis, abdominal mass).

\section{Introduction}

Neuroblastoma is the commonest extracranial solid tumour in children and accounts for $15 \%$ of all paediatric deaths due to malignancies ${ }^{1,2}$. It commonly presents as abdominal pain and abdominal mass. It may present with obstructive jaundice due to bile duct obstruction ${ }^{3-6}$. We report a case of neuroblastoma with acute pancreatitis.

\section{Case report}

An eight year old boy was admitted with a history of abdominal pain for 3 months and abdominal distension for 1 month. The abdominal pain was dull, severe, agonizing, mostly confined to the epigastric region, radiating to the back, aggravated after taking food, relieved by leaning forward and associated with anorexia and diarrhoea. Abdominal distension was gradually worsening (Figure 1). There was no history of taking any drugs such as azathioprine, 6-mercaptopurine, methyldopa or thiazide diuretics and no history of abdominal trauma or previous viral illness. There was, no family history of pancreatitis and no contact history of tuberculosis.

Two days after admission, he developed continuous fever (highest temperature $104^{\circ} \mathrm{F}$ ) and non-bilious vomiting. On examination on day 3 of admission, he was fretful, febrile, had mild pallor, a pulse rate of $84 / \mathrm{min}$, blood pressure of $110 / 70 \mathrm{~mm} \mathrm{Hg}$, a respiratory rate of $34 / \mathrm{min}$ and oxygen saturation (SPO2) of $97 \%$ in room air. Anthropometrically

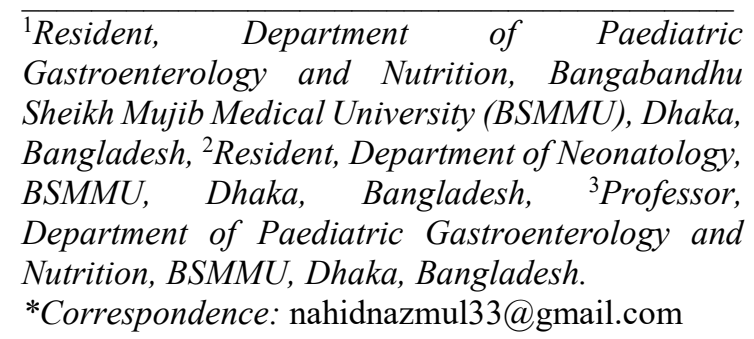

(iD) https://orcid.org/0000-0002-0403-4334

(Keceived on 12 August 2020: Accepted after revision on 18 September 2020)

The authors declare that there are no conflicts of interest

Personal funding was used for the project.

Open Access Article published under the Creative

Commons Attribution CC-BY (cc) (i) License the Wight for Height Z-score (WHZ) was -3.49 and the Height for Age Z-score (HAZ) was -2.7 with age-appropriate development. Generalized lymphadenopathy was present, which was firm in consistency, non-tender, discrete and mobile. The abdomen was distended with slit like umbilicus. An ill-defined mass was present in the umbilical and epigastric regions, firm in consistency with an irregular surface, not attached to skin or underlying structures. There was no organomegaly. Ascites was present. Other system examination was normal.

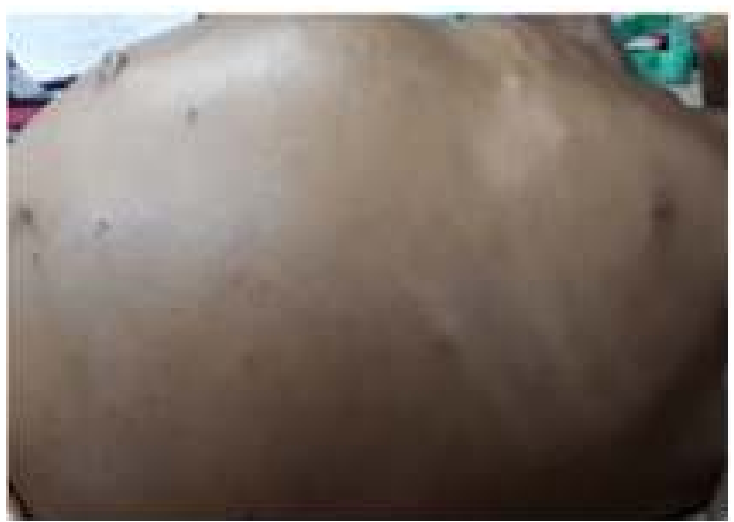

Figure 1: Abdominal distension

Laboratory and radiological investigations are summarised in Table 1. There was microcytic hypochromic anaemia. Serum lactate dehydrogenase, serum lipase and serum alanine aminotransferase were markedly elevated. The ascitic fluid had a low Serum Ascites Albumin Gradient (SAAG). Ultrasonography of abdomen showed moderate ascites, enlarged para-aortic, preaortic, peri-pancreatic and pelvic lymph nodes and a compressed and swollen pancreas. Computerized tomography (CT) of the abdomen showed a swollen pancreas and a mass in the pre and para-aortic region with moderate ascites (Figures 2 and 3). An ultrasound guided biopsy from the abdominal mass was done. Histopathology showed a small round blue cell tumour (Figure 4) and immunohistochemistry showed CD 56 positive in tumour cells compatible with neuroblastoma. After evaluating the clinical data, physical findings, and investigation results, the case was finally diagnosed as neuroblastoma presenting with acute pancreatitis. The patient was referred to paediatric haematology and oncology for protocol-based chemotherapy. 
Table 1: Laboratory and radiological investigations

\begin{tabular}{|c|c|c|}
\hline Investigation & Results & Normal range \\
\hline $\begin{array}{l}\text { Complete Blood Count } \\
\text { Haemoglobin }(\mathrm{g} / \mathrm{dL}) \\
\text { ESR }\left(\mathrm{mm} \text { in } 1^{\text {st }} \mathrm{hr}\right) \\
\text { White blood cell count }(/ \mathrm{cu} \mathrm{mm}) \\
\text { Neutrophils }(\%) \\
\text { Lymphocytes }(\%) \\
\text { Platelet count }(/ \mathrm{cu} \mathrm{mm})\end{array}$ & $\begin{array}{c}10.5 \\
45 \\
10,300 \\
55 \\
36 \\
300,000\end{array}$ & $\begin{array}{c}13-17 \\
0-10 \\
4,500-11,000 \\
40-80 \\
20-40 \\
150,000-400,000\end{array}$ \\
\hline $\begin{array}{l}\text { Liver function tests } \\
\text { Serum albumin }(\mathrm{g} / \mathrm{L}) \\
\text { Prothrombin time }(\mathrm{sec}) \\
\text { International normalized ratio } \\
\text { Alanine aminotransferase }(\mathrm{u} / \mathrm{L})\end{array}$ & $\begin{array}{c}42 \\
10.05 \\
0.88 \\
282\end{array}$ & $\begin{array}{c}35-50 \\
12-16 \\
<1.4 \\
35-50\end{array}$ \\
\hline Serum lipase $(\mathrm{u} / \mathrm{L})$ & 1660 & $0-160$ \\
\hline 24 hours urinary VMA (mg /day) & 6.5 & $5-15$ \\
\hline Serum lactate dehydrogenase $(\mathrm{u} / \mathrm{L})$ & 2023 & $140-250$ \\
\hline Serum creatinine $(\mathrm{mg} / \mathrm{dl})$ & 0.5 & $0.9-1.3$ \\
\hline X-ray chest & Normal & \\
\hline Mantoux test & Negative & \\
\hline $\begin{array}{l}\text { Ascitic fluid study } \\
\text { Total white blood cell count (/cu mm) } \\
\text { Neutrophils }(\%) \\
\text { Lymphocytes }(\%) \\
\text { Lactic dehydrogenase }(\mathrm{u} / \mathrm{L}) \\
\text { Ascites fluid albumin }(\mathrm{g} / \mathrm{dL}) \\
\text { Adenosine deaminase }(\mathrm{u} / \mathrm{l}) \\
\text { Ascitic fluid amylase }(\mathrm{u} / \mathrm{l}) \\
\text { SAAG }(\mathrm{g} / \mathrm{dl})\end{array}$ & $\begin{array}{c}400 \\
15 \\
85 \\
900 \\
3.4 \\
3.5 \\
143 \\
0.8\end{array}$ & $\begin{array}{c}<250 \\
\\
400 \\
0.3-4.0 \\
\text { Up to } 15 \\
50 \% \text { Of serum level }\end{array}$ \\
\hline Ultrasonography of abdomen & \multicolumn{2}{|c|}{$\begin{array}{l}\text { Moderate ascites, Enlarged lymph node- Para -aortic, pre-aortic, } \\
\text { peri -pancreatic \& pelvic. Pancreas is compressed and swollen. }\end{array}$} \\
\hline $\begin{array}{l}\text { Computerized tomography of abdomen } \\
\text { (Figures } 2 \text { and } 3 \text { ) }\end{array}$ & \multicolumn{2}{|c|}{$\begin{array}{l}\text { Pancreas was swollen, a mass in pre and para-aortic region with } \\
\text { moderate ascites }\end{array}$} \\
\hline Histopathology (Figure 4) & \multicolumn{2}{|c|}{$\begin{array}{l}\text { Small round blue cell tumour. Tumour cell have dark round to } \\
\text { oval nuclei and small amount of cytoplasm. A few perivascular } \\
\text { pseudo-rosettes are present. }\end{array}$} \\
\hline Immunohistochemistry & \multicolumn{2}{|c|}{ CD 56 positive in tumour cells compatible with neuroblastoma } \\
\hline
\end{tabular}

ESR: erythrocyte sedimentation rate, VMA: vanillyl mandelic acid, SAAG: serum ascites albumin gradient

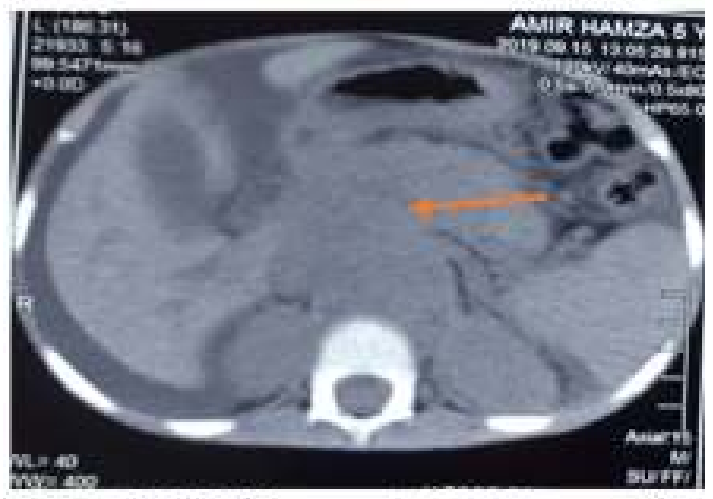

Figure 2: CT abdomen. Arrow shows swollen pancreas along with pre-aortic lymph node

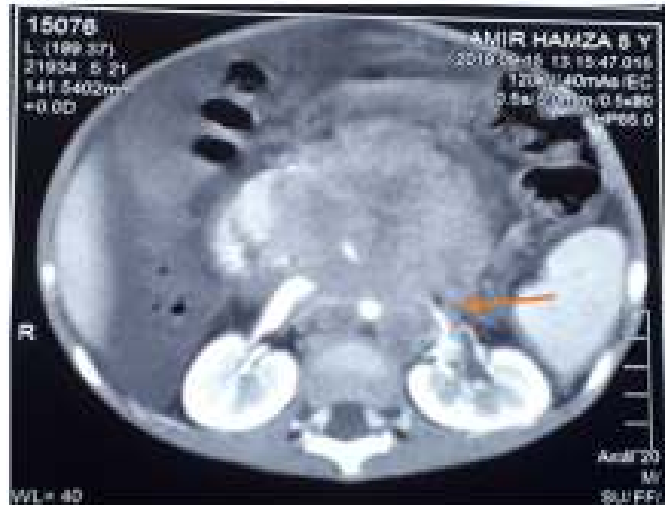

Figure 3: CT abdomen. Arrow shows a mass which is compressing renal vessels 


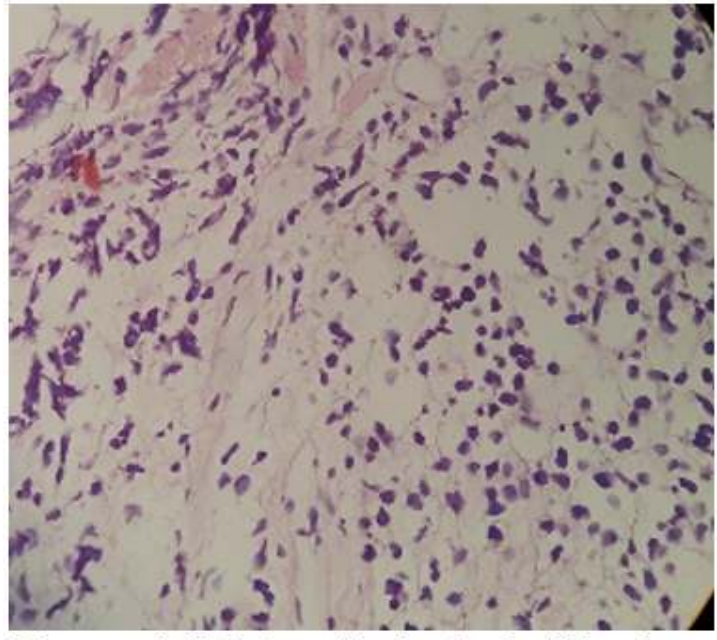

Figure 4: Histopathological slide show small round blue cells

\section{Discussion}

Around $90 \%$ of children with neuroblastoma are diagnosed before 5 years of age ${ }^{7}$. Our patient was 8 years old when diagnosed. About $60 \%$ of primary neuroblastomas arise in the abdomen and commonly present with fixed and firm abdominal mass, abdominal pain, protein losing enteropathy, ascites and weight $\operatorname{loss}^{8}$. Hepatobiliary obstruction is a rare complication of neuroblastoma and pancreatic ductal obstruction was reported in one case 9 . Our patient had pancreatitis which is a rare presentation of neuroblastoma and it may have occurred due to pancreatic ductal obstruction by tumour invasion of the head of the pancreas and due to cytokines released from the tumour e.g. TNF- $\alpha$ and IL- $\beta$. Regional lymph node metastases are noted in $35 \%$ of patients with apparently localized neuroblastoma ${ }^{8}$. Our patient had generalized lymphadenopathy.

Diagnosis of acute pancreatitis is made if the patient presents with at least two of the following three manifestations: acute attack of characteristic abdominal pain, elevated levels of pancreatic leaking enzymes and findings of the pancreas detected by USG, CT or magnetic resonance imaging (MRI) ${ }^{10}$. Our patient had abdominal pain, elevated pancreatic enzyme and swollen pancreas on USG and CT scan. Intra-abdominal malignancy especially neuroblastoma may be a rare cause of pancreatitis. Neuroblastoma should be considered in the differential diagnosis if a child presented with abdominal mass and pancreatitis.

\section{References}

1. Davidoff AM. Neuroblastoma. Seminars in Pediatric Surgery 2012; 21:2-14. https://doi.org/10.1053/j.sempedsurg.2011 .10 .009

PMid: 22248965 PMCid: PMC3261589

2. Chu CM, Rasalkar DD, Hu YJ, Cheng FW, Li CK, Chu WC. Clinical presentations and imaging findings of neuroblastoma beyond abdominal mass and a review of imaging algorithm. British Journal of Radiology 2011; 84:81-91.

https://doi.org/10.1259/bjr/31861984

PMid: 21172969 PMCid: PMC3473807

3. Gow KW, Blair GK, Phillips R, et al. Obstructive jaundice caused by neuroblastoma managed with temporary cholecystostomy tube. Journal of Pediatric Surgery 1995; 30: 878-82.

https://doi.org/10.1016/00223468(95)9077 $1-8$.

4. Ito A, Uno T, Gunji Y, Yamauchi T, Egami $\mathrm{S}$, Kawarasaki $\mathrm{H}$, et al. Obstructive jaundice as a presentation of ganglioneuroblastoma. Journal of Pediatric Hematology/Oncology 2005; 27(2): 112-4.

https://doi.org/10.1097/01.mph.00001534 45.20945.fd

PMid: 15701990

5. Okada T, Yoshida H, Matsunaga T, Kouchi $\mathrm{K}$, Ohtsuka $\mathrm{Y}$, Tsuyugushi $\mathrm{T}$, et al. Endoscopic internal biliary drainage in a child with malignant obstructive jaundice caused by neuroblastoma. Paediatric Radiology 2003; 33:133-5. https://doi.org/10.1007/s00247-002-07819

PMid: 12557071

6. Walsh MT, Shah KJ. Neuroblastoma presenting with obstructive jaundice. British Journal of Radiology 1989; 62:624-6.

https://doi.org/10.1259/0007-1285-62-

739-624

PMid: 2758252

7. Colon NC, Chung DH. Neuroblastoma. Advances in Pediatrics 2011; 58(1): 297311.

https://doi.org/10.1016/j.yapd.2011.03.01 1

PMid: 21736987 PMCid: PMC3668791

8. Hallett A, Traunecker H. A review and update on neuroblastoma. Paediatrics and Child Health 2012; 22(3): 103-7.

https://doi.org/10.1016/j.paed.2011.08.005 
9. Fishman DS, Manfredi MA, LaBelle JL, Levine JE, Shamberger RC, Rufo PA. Pancreatitis as the initial manifestation of stage IV neuroblastoma. Journal of Paediatric Gastroenterology and Nutrition 2007; 44:146-8.

https://doi.org/10.1097/01.mpg.00002359

73.29378.fb

PMid: 17204969
10. Wang GJ, Gao CF, Wei D, Wang C, Ding SQ. Acute pancreatitis: Aetiology and common pathogenesis. World Journal of Gastroenterology 2009; 15(12):1427-30. https://doi.org/10.3748/wjg.15.1427

PMid: 19322914 PMCid: PMC2665136 